\title{
Ghosts of Sorrow, Sin and Crime: Dark Tourism and Convict Heritage in Van Diemen's Land, Australia
}

\author{
Eleanor Conlin Casella ${ }^{1} \cdot$ Katherine Fennelly $^{1,2}$
}

Published online: 1 August 2016

(C) The Author(s) 2016. This article is published with open access at Springerlink.com

\begin{abstract}
Established as a British imperial penal colony, Van Diemen's Land received approximately 75,000 convicts before cessation of convict transportation in 1853. A vast network of penal stations and institutions were created to accommodate, employ, administer, and discipline these exiled felons. Popular interpretations of Australia's convict past highlight dynamics of shame, avoidance and active obliteration that characterized Australia's relationship to its recent convict past. Yet, closer examination of these colonial institutions suggests a far more ambivalent relationship with this "dark heritage," evidenced by continuous tourism and visitation to these places of pain and shame from the mid-nineteenth century to the present.
\end{abstract}

Keywords Institutions $\cdot$ Dark tourism $\cdot$ Penal $\cdot$ Colonial archaeology $\cdot$ Australia

\section{Introduction}

Tourism to sites and institutions for convict transportation in Tasmania tells a complex story of simultaneous repulsion and attraction, and suggests a broader acceptance of the origins of colonial-period history in Australia than has previously been acknowledged. In 1853, the transportation of convicts to the penal colony of Van Diemen's Land was formally ceased, and 3 years later, the island was renamed Tasmania. Nevertheless, the colony maintained a notorious reputation, its past inexorably linked to enduring legacies of the "convict stain." The dominant historical narrative throughout the latter half of the twentieth century claims that Australia's convict origins were not publically

Eleanor Conlin Casella

E.Casella@manchester.ac.uk

Katherine Fennelly

k.fennelly@sheffield.ac.uk

1 Department of Archaeology, University of Manchester, Manchester, UK

2 Department of Archaeology, University of Sheffield, Sheffield, UK 
embraced until the early 1960s. Closer examination reveals that Australians retained a far more ambiguous relationship with their problematic colonial heritage. Indeed, tourism and heritage associated with convict institutions is a significant contributor to the Tasmanian state economy today (Lawrence and Davies 2011, p. 19).

The enduring popularity of tourism on the Sarah Island penal establishment is apparent in the infrastructure that supports visits, and local engagement with this infamous site. Providing the focal case study for this paper, both Sarah Island and its unique surrounding environment, sit within the broader imperial and institutional history of the Van Diemen's Land penal colony, evolving narratives of convict heritage, and the persistent (if ambivalent) relationship of dark tourism (Lennon and Foley 2000) to these grim places.

\section{Not Very Uncomfortable: Sarah Island and Tourism Over the Convict Era}

The ruins of the penal establishment on Sarah Island are the most substantial material remains of what was once a busy colonial institutional landscape. The island is dotted with the overgrown remnants of service buildings such as a bakehouse and tannery, as well as accommodation buildings for both officers and convicts. These ruined buildings signify a colonial imposition on the otherwise pristine rainforest landscape. Anthropologist Ann Laura Stoler (2008, p. 202) has found large-scale ruination an organized undertaking, typically state-sponsored and politically motivated (see also Pétursdóttir and Olsen 2014). Indeed, the ruination of Sarah Island began during the island's use as a convict settlement, the structural decay itself reflecting a process of concerted, if not intentional, neglect born through a combination of government bureaucratic austerity and inefficiencies, the ambivalent role of this infamously grim establishment within this highly self-conscious British penal colony, and relentless encroachments by the surrounding damp rainforest. Nevertheless, constant tourism to this site from the nineteenth century to the present day also demonstrates a simultaneous interest and concern amongst the public with Australia's colonial origins and darker institutional history. The enduring public interest in sites of colonial settlement articulates with increasingly formalized tourism to sites with "dark" and difficult histories.

Commemoration of places associated with the tragic facets of human experience immediately begs complex questions of ethics, representation, testimony, personal identification, and collective memory (Smith 2006). Drawing from the influential work of John Lennon and Malcolm Foley (2000), Laura McAtackney (2014, p. 226) observed that the term dark heritage "specifically links the growing tourist appetite for consuming sites of death and destruction as manifestations of western, global consumerism - and therefore recent vintage - reflecting the circumstances of the late modern world." Strong antecedents of this lurid appetite can be traced back through the nineteenth and eighteenth centuries - arguably even into the seventeenth century - as gentry philanthropists, clergy, and politicians fascinated and horrified themselves in equal measure with day visits through the hospitals, asylums, and prisons of Europe and North America. Not all public tours of these institutions for confinement were voyeuristic in nature; reformers, writers, and concerned members of the public were often facilitated in visiting institutions in order to educate, to inform, and sometimes to assure the public that these buildings were fit for purpose (Miron 2011, pp. 36-41). "Dark" tourism to these sites of human confinement has often served multiple complex, and sometimes 
competing, purposes. Far from emerging in the context of western, global consumerism, the roots of dark tourism at the Macquarie Harbor Penal Establishment were first planted in the early decades of the nineteenth century-during its first years of operation as a remote carceral landscape centered on Sarah Island (Fig. 1).

In 1822, a small island inside Macquarie Harbor on the remote southwest coast of Van Diemen's Land was established as a penal colony for refractory male prisoners

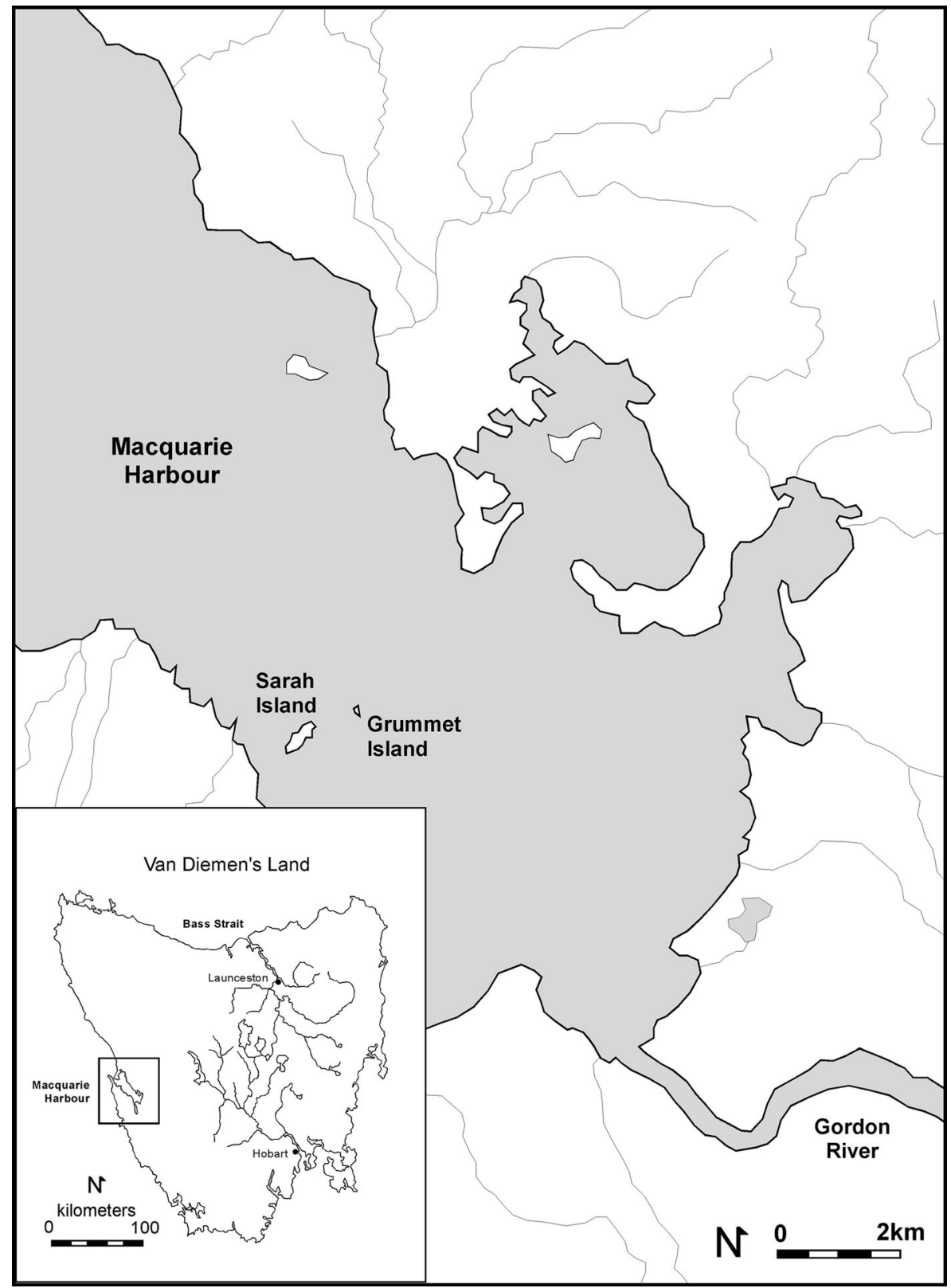

Fig. 1 Location Map, Tasmania, Macquarie Harbor, and Sarah Island 
under British imperial sentence. Since no overland passage existed between the colonial capital of Hobart Town and the southwest coast, both convicts and provisions were transported under sail, a rough journey navigating the southern coast that took up to 6 weeks, and culminated in the perilous negotiation of the silted harbor entrance known as Hell's Gates (Maxwell-Stewart 2008, p. 14). Convicts primarily labored at timber felling, with outstation labor camps distributed around the harbor, the logs and men being ferried back to Sarah Island each night. Though the Macquarie Harbor penal settlement could house up to 370 convicts at any given time, the average number of convicts was 245 between 1822 and 1826 (Hughes 2010, p. 377).

Begun in early 1826, the small gaol on the eastern side of Sarah Island consisted of a brick structure with suspended timber floors, laid upon sandstone foundations (Backhouse 1843). Measuring $45 \mathrm{ft}(14 \mathrm{~m})$ by $17 \mathrm{ft}(5 \mathrm{~m})$, it was completed by convict labor during 1827, and consisted of three zones: a reception room used for the accommodation of guards; an access corridor along the full length of the northern interior; and a block of six cells, each roughly $7 \mathrm{ft}(2 \mathrm{~m})$ long by $3 \mathrm{ft}(1 \mathrm{~m})$ wide, with wooden ceilings installed at $9 \mathrm{ft}(3 \mathrm{~m})$ high. For sanitation purposes, interior walls were whitewashed, and air circulation passed through ceiling and corridor vents. The gaol provided a combination of holding cells for convicts awaiting their trial date at the Hobart Town courts, and solitary punishment cells. Because of these mixed functions, up to 15 convicts were accommodated within the gaol, or almost three men per individual cell (Tasmanian Archives and Heritage Office 1828).

Tourism to the site began while the penal station was still in operation. High-profile visitors to the Macquarie Harbor Penal Establishment included James Backhouse and George Washington Walker in 1832. Quaker missionaries sent from Britain by the London Yearly Meeting, they together became known as "The Conscience of the Colony" due to their frank public reports on penal conditions within Van Diemen's Land (Backhouse 1843). During their stay at Macquarie Harbor, the number of prisoners including those accommodated in remote labor camps around the harbor, totaled 177. The Backhouse and Walker report on Sarah Island offered general approval at the state of prisoner accommodation, describing "huts of the humblest construction" but "being furnished with good fires were not very uncomfortable, particularly when the inmates whitewashed them, and kept them clean" (Backhouse 1843, pp. 53-54). Nevertheless, their report also documented the brutality of life at Macquarie Harbor, observing that over its initial 11 years of operation between 1822 and 1833, out of a total death count of 85 convicts only 35 resulted from natural causes. The other 50 were attributed to drowning, logging accidents, execution by military guards, and murder by fellow prisoners. Additionally, out of the 112 men who had attempted escape, 62 were believed to have perished in the surrounding temperate rainforest, and nine were murdered by their fellow absconders in acts of cannibalism (Oats 1981, p. 33). In total, over this first period of operation, approximately 1,127 convicts had been put to work either directly on Sarah Island or logging on tiny outstations dispersed around the southern reaches of Macquarie Harbor.

With the establishment of large penal stations at Port Arthur and Maria Island on the far more accessible eastern coast of Van Diemen's Land during the early 1830s, Sarah Island became a remote, inhospitable and costly burden on the Convict Department, and was initially abandoned in 1833 . While the overall settlement fell rapidly into disrepair, the Gaol survived relatively intact. By the 1840s, changes in British 
correctional policies led to the establishment of "probation stations" across Van Diemen's Land for distribution of convict work gangs across various government run projects. Appointed Lieutenant-Governor of Van Diemen's Land in 1836, Sir John Franklin drew upon his previous experience with arctic expeditions in northern Canada to mount an overland trek across the wild uninhabited center of the island over April and May of 1842 with his wife and a variety of gentlemen scientists, military constables, and convict couriers. The Franklin Party emerged on the remote west coast, and promptly extended their journey by sailing across Macquarie Harbor to explore the overgrown remains of the abandoned penal island (Alexander 2013, pp. 154-159). According to David Burn, a recent free immigrant and diarist who accompanied the tour party, Sarah Island cast an appropriately macabre atmosphere: "Here was a once busy, striving port, fast returning to primeval loneliness of man and his creations smouldering to unmarked and rapid decay... Who could regard its solitary workshops without conjuring the ghosts of sorrow, sin and crime!" (Burn 1842, p. 47). He also noted that the cells of the overgrown gaol remained dry and well ventilated, although the walls were covered in a large amount of remnant convict graffiti-including "pendulous pictures" by "JH 1821" and the message "Daniel O'Connell, the Man of the People!" inscribed by an anonymous Irish agitator.

Following the Franklin Overland Trek, Sarah Island was briefly re-established as a Probation Station for timber cutting, with 162 convicts and a detachment of officers delivered to the derelict prison in April 1846 (Brand 1984, p. 75). The gaol was once again occupied, although interior modifications over this period included the removal of (presumably rotten) suspended timber floors in the reception room, and the demolition of three interior dividing walls to transform the six cells into two larger rooms.

Despite substantial investment in penal infrastructure across Van Diemen's Land, the "Probation System" also proved an expensive failure (Brand 1990), and after only 12 months' operation, the Sarah Island Penal Station was permanently closed. Almost immediately upon its final abandonment by the Convict Department, the island fell into casual civilian use by local residents of Macquarie Harbor, providing both a refuge during fierce storms, and a storage depot for timbering, fishing and hunting parties. Finally, as popular curiosity grew over the convict legacy of Van Diemen's Land, local sailors charged tour groups for daytrips to the dilapidated ruins of Sarah Island (Fig. 2). Thus, from 1847 onwards, post-convict era use of the gaol became associated with two separate but linked activities: casual exploitation of the harbor resources by local residents, and dark tourism enjoyed by locals and visitors alike.

\section{Falling into Decay: An Archaeology of Dark Tourism}

What would constitute the archaeological signature of these post-convict era uses of the site? Could we characterize the nature of dark tourism at this remote and infamous World Heritage site? In March 2010, the Sarah Island Archaeology Project was created as a collaboration between the University of Manchester and the Tasmanian Parks and Wildlife Service to examine the nature, extent, and preservation conditions of subsurface remains within the historic gaol. In addition to deposits and assemblages linked to both convict periods of occupation, archaeological excavations revealed the presence of cultural materials associated with post-convict era use of Sarah Island. Following a 


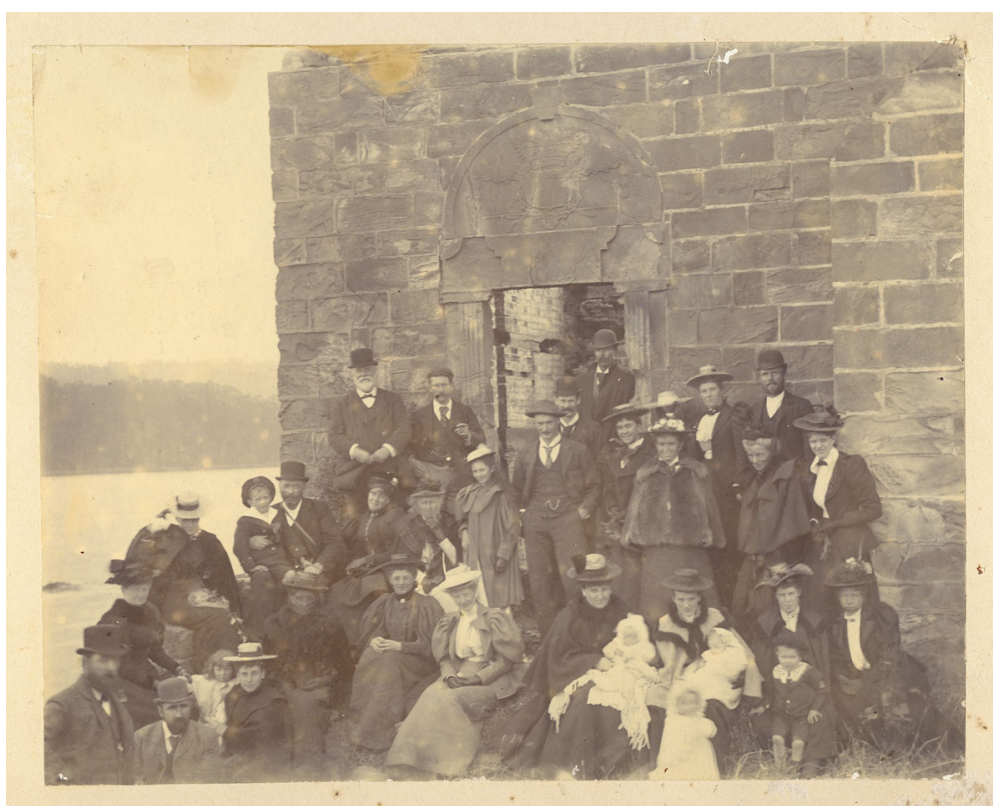

Fig. 2 Dark Tourism, 1890s. (Tasmanian Archives and Heritage Office)

brief discussion of methodologies, this paper will consider analysis results in order to explore the material patterns of visitor activities within the ruins of this punishment structure.

\section{Sarah Island Archaeology Project 2010}

Two trenches were opened within the study area, exposing a total of three discrete structural zones: the Reception and the Chimney (both Trench 1), and the Rear (Trench 2). Features located within Trench 1 included the original 1826 sandstone gaol foundations and surviving exterior brick walls, with the presence of joist slots indicating the original orientation of suspended timber floor within the Reception room. Excavations also revealed structural modifications associated with the brief 1846-47 period of site use, including demolition of the dividing wall between the Reception and first cell. Subsequently, the recovered bricks had been recycled to construct both a free-standing fireplace feature inside the first cell (the chimney), and a paved hearth floor within the Reception.

Following the final abandonment of the penal station, substantial deposits of soils and demolition debris had accumulated over the front of the gaol, with associated finds suggesting frequent use of the structure from the 1850s onwards. Ever increasing visitor numbers eventually led the Tasmanian Parks and Wildlife Service to introduce formal tourist infrastructure to the island, including a suspended walkway over and into the ruins of the gaol during July 1985 (McGowan 1986). Now itself derelict and partially removed, this more contemporary feature was archaeologically present within Trench 1 as a series of heavily corroded concrete and steel piers sunk into the postconvict period deposits. 
Located at the rear of the structure, Trench 2 examined remains of the rear two cells of the gaol. While both the original 1826 sandstone foundations and exterior brick walls were standing intact, the dividing interior wall had been removed during the 1846 modifications, transforming the space into a single dark room. Unlike in the reception zone, the original timber floors had been left to decay in situ, eventually creating ghostly linear stain features as post-convict era soils accumulated in the abandoned structure. A variety of post-convict period finds were present within these later deposits (see Results of Functional Analysis).

During field excavations, all stratigraphic layers of soil and fine demolition debris were dry screened through both 5 and $2.5 \mathrm{~mm}$ sieves. Artifacts were primarily collected by lot provenance, and bagged by fabric type in association with their stratigraphic context number. Undertaken at the University of Manchester, post-excavation laboratory methods involved the identification, cataloguing, and analysis of all recovered assemblages. To support the comparative value of this convict-related collection, classification and cataloguing methods previously developed for cognate Tasmanian projects at Port Arthur (Davies and Buckley 1987, pp. 184-189) and the Ross Female Factory (Casella 2001) were adopted. Artifacts were first categorized into one of four fabric types: ceramic, glass, metal, or "other" - bone, shell, seed, coal, leather, mortar and plaster, plastic, rubber, stone and wood (including charcoal). Further stages of classification were applied to identify ceramics by type of production, decoration, and (where possible) vessel form, glass by vessel form and color, and metals by composition type. Since recovered finds proved to be particularly fragmented, vessel form was frequently difficult to determine. Therefore, minimum number (MNI) counts were interpreted from differences in fabric and decorative characteristics of the items within each stratigraphic assemblage.

Through a combination of stratigraphic and historical analysis, a total of 38 depositional contexts were linked to the post-convict period of site use (1847-present), and subjected to a final stage of functional analysis. As before, classification methods were adopted from those used at the Ross Female Factory (Casella 2001) in order to promote future comparative research on Tasmanian convict heritage sites.

\section{Results of Functional Analysis}

Specific functional classification categories present within the gaol assemblages consisted of: Clothing, Diet, Domestic, Ecofact, Fuel, Indulgence, Literacy, Sport, Social Control (objects related to the physical enforcement of domination), and Structural. Table 1 presents all data related to the following discussions. Where MNI estimates could be calculated, the count was separated from the total weight (in grams) by a semi-colon.

Overall, less cultural material was recovered from the rear of the gaol than the reception and chimney zones. Copies of historic photos from the Parks and Wildlife Service site files indicated that the roof was no longer present by the late nineteenth century. Therefore, although the general depositional pattern suggested that visitors made alternative uses of the rear interior versus front of the structure, these differences did not appear to relate to the amount or quality of light available within the derelict gaol. By weight, the vast majority of the Sarah Island finds consisted of whitewashed soft terracotta bricks with graffiti inscriptions. These items were also concentrated 
Table 1 Functional analysis results

\begin{tabular}{|c|c|c|c|c|}
\hline Assemblage & & Reception & Chimney & Rear \\
\hline \multirow[t]{5}{*}{ Clothing } & Button & $2.2 \mathrm{~g} ; 2$ & $0.6 \mathrm{~g} ; 1$ & $0.6 \mathrm{~g} ; 1$ \\
\hline & Copper pin & $0.2 \mathrm{~g} ; 1$ & $0 \mathrm{~g}$ & $0 \mathrm{~g}$ \\
\hline & Copper fastener & $0 \mathrm{~g}$ & $0 \mathrm{~g}$ & $3 \mathrm{~g} ; 1$ \\
\hline & Shoe fragments & $0 \mathrm{~g}$ & $0 \mathrm{~g}$ & $11.2 \mathrm{~g}$ \\
\hline & Total & $2.4 \mathrm{~g}$ & $0.6 \mathrm{~g}$ & $14.8 \mathrm{~g}$ \\
\hline \multirow[t]{4}{*}{ Domestic } & Ceramic & $128.1 \mathrm{~g} ; 10$ & $189.0 \mathrm{~g} ; 11$ & $8.8 \mathrm{~g} ; 5$ \\
\hline & Storage barrel fragments & $1256.1 \mathrm{~g}$ & $98.4 \mathrm{~g}$ & $4481.1 \mathrm{~g}$ \\
\hline & Cooking plate & $1062 \mathrm{~g} ; 1$ & $0 \mathrm{~g}$ & $0 \mathrm{~g}$ \\
\hline & Total & $2446.2 \mathrm{~g}$ & $287.4 \mathrm{~g}$ & $4489.9 \mathrm{~g}$ \\
\hline \multirow[t]{3}{*}{ Ecofact } & Bone & $26.5 \mathrm{~g}$ & $10.8 \mathrm{~g}$ & $39.2 \mathrm{~g}$ \\
\hline & Swan shell & $118.6 \mathrm{~g}$ & $42.9 \mathrm{~g}$ & $0 \mathrm{~g}$ \\
\hline & Total & $145.1 \mathrm{~g}$ & $53.7 \mathrm{~g}$ & $39.2 \mathrm{~g}$ \\
\hline \multirow[t]{2}{*}{ Fuel } & Charcoal & $10 \mathrm{~g}$ & $1 \mathrm{~g}$ & $0.8 \mathrm{~g}$ \\
\hline & Total & $10 \mathrm{~g}$ & $1 \mathrm{~g}$ & $0.8 \mathrm{~g}$ \\
\hline \multirow[t]{3}{*}{ Indulgence } & White clay tobacco pipes & $4.6 \mathrm{~g} ; 2$ & $0 \mathrm{~g}$ & $6.4 \mathrm{~g} ; 3$ \\
\hline & Olive bottle glass & $875.4 \mathrm{~g} ; 6$ & $45.0 \mathrm{~g} ; 3$ & $175.1 \mathrm{~g} ; 8$ \\
\hline & Total & $880 \mathrm{~g}$ & $45.0 \mathrm{~g}$ & $181.5 \mathrm{~g}$ \\
\hline \multirow[t]{5}{*}{ Diet } & Condiment & $68.2 \mathrm{~g} ; 4$ & $4.2 \mathrm{~g} ; 2$ & $3.6 \mathrm{~g} ; 2$ \\
\hline & Food tins & $6.4 \mathrm{~g}$ & $6.8 \mathrm{~g}$ & $52.6 \mathrm{~g}$ \\
\hline & Sodawater & $152.0 \mathrm{~g} ; 2$ & $0 \mathrm{~g}$ & $0 \mathrm{~g}$ \\
\hline & Aluminium - other & $3.6 \mathrm{~g}$ & $4.4 \mathrm{~g}$ & $0 \mathrm{~g}$ \\
\hline & Total & $230.2 \mathrm{~g}$ & $15.4 \mathrm{~g}$ & $56.2 \mathrm{~g}$ \\
\hline \multirow[t]{2}{*}{ Sport } & Shell casing & $3.0 \mathrm{~g} ; 2$ & $13.8 \mathrm{~g} ; 4$ & $0 \mathrm{~g}$ \\
\hline & Total & $3.0 \mathrm{~g}$ & $13.8 \mathrm{~g}$ & $0 \mathrm{~g}$ \\
\hline \multirow[t]{3}{*}{ Literacy } & Slate pencil & $0 \mathrm{~g}$ & $1.4 \mathrm{~g} ; 1$ & $0 \mathrm{~g}$ \\
\hline & Slate tablet & $8.8 \mathrm{~g}$ & $0 \mathrm{~g}$ & $0 \mathrm{~g}$ \\
\hline & Total & $8.8 \mathrm{~g}$ & $1.4 \mathrm{~g}$ & $0 \mathrm{~g}$ \\
\hline \multirow[t]{2}{*}{ Social control } & Chains & $0 \mathrm{~g}$ & $0 \mathrm{~g}$ & $15.4 \mathrm{~g}$ \\
\hline & Total & $0 \mathrm{~g}$ & $0 \mathrm{~g}$ & $15.4 \mathrm{~g}$ \\
\hline \multirow[t]{12}{*}{ Structural } & Brick - whitewashed & $19255 \mathrm{~g} ; 15$ & $0 \mathrm{~g}$ & $265 \mathrm{~g} ; 1$ \\
\hline & Mortar/plaster & $4.4 \mathrm{~g}$ & $0 \mathrm{~g}$ & $6.3 \mathrm{~g}$ \\
\hline & Ferrous nail & $883.8 \mathrm{~g} ; 84$ & $545.6 \mathrm{~g} ; 66$ & $428.7 \mathrm{~g} ; 34$ \\
\hline & Ferrous other & $123.9 \mathrm{~g}$ & $100.8 \mathrm{~g}$ & $1.6 \mathrm{~g}$ \\
\hline & Copper-alloy nail & $0 \mathrm{~g}$ & $0 \mathrm{~g}$ & $105.2 \mathrm{~g} ; 3$ \\
\hline & Lead & $204.2 \mathrm{~g}$ & $0 \mathrm{~g}$ & $7.6 \mathrm{~g}$ \\
\hline & Clear window glass & $2.4 \mathrm{~g}$ & $5.6 \mathrm{~g}$ & $4.3 \mathrm{~g}$ \\
\hline & Floorboards & $0 \mathrm{~g}$ & $0 \mathrm{~g}$ & $1018 \mathrm{~g}$ \\
\hline & Wood - other (fittings) & 4057.2 g; (98 nails) & $105.8 \mathrm{~g}$ & $61 \mathrm{~g}$ \\
\hline & Plastic - other & $0 \mathrm{~g}$ & $0 \mathrm{~g}$ & $1.2 \mathrm{~g}$ \\
\hline & Burnt glass & $0 \mathrm{~g}$ & $0 \mathrm{~g}$ & $0.8 \mathrm{~g}$ \\
\hline & Total & $24530.9 \mathrm{~g}$ & $757.8 \mathrm{~g}$ & $1899.7 \mathrm{~g}$ \\
\hline Total (g) & & $28256.6 \mathrm{~g}$ & $1176.1 \mathrm{~g}$ & $6697.5 \mathrm{~g}$ \\
\hline
\end{tabular}


within the front zones, with 15 bricks $(19,255 \mathrm{~g}$, or approximately $68 \%$ of the Trench 1 collection) recovered from the reception and chimney, compared to a single example found in the rear. This pattern was a likely result of post-convict period demolition activities; the front of the gaol had been primarily removed down to its sandstone foundations and left as accumulated layers of debris (including the bricks) within Trench 1, while the exterior brick walls of the rear were left intact to roof height, their whitewashed faces and all graffiti scoured away by gradual weather exposure.

Inscriptions tended towards ambiguous figurative or linear markings, although one brick was clearly marked "John D for robbing" (Fig. 3). The handwritten name visibly folded back the edges of remnant limewash - a tiny material detail that suggested the coating of wash had been wet at the moment of inscription, and therefore most likely done by a male convict during active maintenance of the gaol before its final abandonment in 1847 . Indeed, this writing was subsequently overlaid by later markings by later visitors to the gaol structure, thereby graphically demonstrating the palimpsest of use that so characterizes institutional graffiti. The other major element of this collection consisted of the original wooden front door. Recorded as a linear scatter of 98 forged ferrous rosehead nails, many with remnant wood attached (4,057.2 $\mathrm{g}$ in total), this ghostly feature appeared to have collapsed into the reception room and rotted in situ.

While slightly more Clothing related finds were recovered from the reception and chimney areas of the gaol, this functional category was dominated by the presence of $11.2 \mathrm{~g}$ of leather shoe fragments in Trench 2 (see Table I). Domestic artifacts also demonstrated spatial distribution patterns, with the majority of ceramics concentrated in the front of the structure, and ferrous barrel fragments recovered from the rear. Appearing as two separate iron hoops that would have reinforced wooden barrels, these highly fragile artifacts were recorded in situ before removal. Since Sarah Island has no natural source of fresh water, the barrels suggested water storage at the rear of the gaol after 1847 , thereby providing tourists and locals with essential drinking water while they adventured through Macquarie Harbor.

Within the Diet category, ferrous food tins appeared to be similarly concentrated at the rear of this structure. Identified by their rolled ends and thin flat shape, those

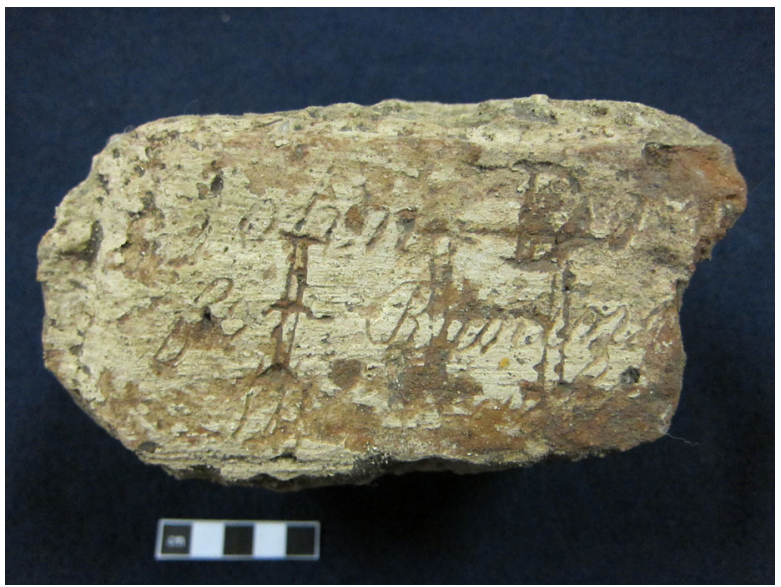

Fig. 3 Graffiti Brick (Sarah Island Archaeology Project 2010) 
recovered from Trench 2 (52.6 g) represented approximately $80 \%$ of this total assemblage, as opposed to only $13.2 \mathrm{~g}$ from Trench 1 . Although categorized under Social Control in accordance with this specific classification system, the fragments of ferrous chain (15.4 g) recovered from post-1847 deposits were likely used as part of winches - securing boats and timber logs rather than convicts workers. Finally, three copper-alloy boat spikes (105.2 g) were recovered from Structural deposits located at the rear. Used to secure planks to the hull frame of a wooden boat, these nails appeared unused, as all three displayed intact casting seams along their heads and shafts. While they may have been used for building (versus maritime) purposes, their presence in the post-convict deposits at the rear suggested they were primarily intended for emergency boat repair, with the ruined gaol used to stash essential replacement parts next to a supply of fresh water, tins of food and extra boots in case of troubles while sailing across Macquarie Harbor.

Assemblages from the front zones of the gaol suggested an entirely different set of activities. In the Domestic category, ceramics concentrated in the front of the gaol, with an MNI count of 21 vessels $(317.1 \mathrm{~g})$ recovered from deposits in the reception and chimney zones. This assemblage tended towards serving and food consumption, with six bowls, two transfer-printed cups, and three transfer-printed plates (either "Willow" or "Asiatic Pheasant" patterns) present in Trench 1. In contrast, excavations within the rear only recovered five vessels $(8.8 \mathrm{~g})$ - two small transfer-printed plate fragments, a molded blue bowl rim sherd, and two pieces of a white-glazed earthenware bowl. The assemblage was extensively water damaged, suggesting the items may have been collected by visitors from midden erosion along the nearby shoreline, and subsequently deposited into the back of the gaol.

Analysis of the recovered bottle assemblages suggested a similar pattern of food consumption focused at the front of Sarah Island's Gaol, with far more vessels related to liquid consumption present. Although the MNI estimates for olive glass bottles (Indulgences category) were evenly spread across the front and rear zones, a far greater weight and diversity of vessel types were recovered from Trench 1 (920.4 g) versus Trench 2 (175.1 g). Additionally, the fragmentary body and shoulder of one particular beer bottle, partially reconstructed by the field conservator, constituted the largest component of the rear bottle assemblage (69 g). While a combination of beer, champagne and gin case bottles were recovered from the front of the gaol, the vast majority of weight $(662.4 \mathrm{~g})$ resulted from two intact bases of nineteenth-century manufacture (Jones and Sullivan 1989). By weight, the base of a brown stoneware ginger beer bottle-the only example of this artifact type recovered from the post-convict era depositsrepresented approximately $77 \%$ of ceramics (Domestic category) recovered from the chimney zone. All soda water vessels (Diet) were recovered from the reception, including a nineteenth-century Codd bottle, represented by not only broken closure and neck fragments, but the separate glass marble stopper (Boow 1991, p. 134). An MNI count of six condiment bottles (Diet, $68.2 \mathrm{~g}$ ) was found in the reception and chimney, compared with two small fragments $(3.6 \mathrm{~g})$ in the rear. In general, body fragments dominated the glass collection, versus the high proportion of rim fragments present in the ceramics, thereby suggesting that after their meal, visitors had deposited their waste bottles within the gaol, while returning home with their ceramics bowls and plates. 
Four final categories of artifacts demonstrated the dominance of food related activities within the front of the gaol. Light, fragile and crumpled in form, approximately $8.0 \mathrm{~g}$ of aluminum foil (Diet) was recovered exclusively from deposits accumulated within Trench 1. Additionally, an unusual concentration of egg shell (Ecofact) was recovered from a combination of the reception (118.6 g) and chimney (42.9 g), and later identified as Cygnus atratus, a locally prolific indigenous species of black swan. Finally, a large ferrous cooking plate (Domestic, 1,062 g) was discovered inside the modified cellblock fireplace of Trench 1 , and a focal concentration of charcoal sweepings (Fuel) appeared atop the brick hearth paving of this heritage feature.

When considered together, this unique artifact collection suggested a material signature of two distinct post-convict period uses of the gaol. Following abandonment of the Sarah Island penal station, the rear section of this structure was likely re-used for storage purposes, with local residents stashing essential resources such as fresh water, tinned food, replacement boots, and extra work equipment (winch chains and boat repair nails) inside the remnant walls. Meanwhile, given the eternal attraction of these atmospheric ruins, the front of these gloomy vestiges of the convict period were used for picnics, the visitors using the derelict brick fireplace for boiling up a brew of tea and locally collected swan eggs to accompany their luncheon parties. Depositing their used bottles on-site, they primarily brought their crockery home for washing and reuse.

\section{A Dark Fascination: The Continuous and Curious Allure of Macquarie Harbor}

Whether as a penal colony or a site of dark tourism, Sarah Island has always been part of a colonial institutional network, with unregulated public engagement with the site being enduring and varied. The island has been used variously as a picnic location, a theatrical stage, and a shooting range - as well as an exotic destination for tourism. This final section will account for the later history of the site, and explore the processes by which Sarah Island has been adapted from a colonial institution of punishment, to both a local amenity, and a component of the broader institution of Tasmanian and UNESCO heritage.

Unregulated tourism to Sarah Island has been popular for nearly 200 years, as supported by the large amount of material culture associated with this activity. Photographs held in the Tasmanian Archives and Heritage Office depict Victorian and Edwardian tourists, mostly white and middle- to upper-class (see Fig. 2). Class has ironically been a significant factor in tourism to Sarah Island since it was settled. Lord and Lady Franklin were able to visit the site in 1842 in consequence of their wealth, as much as their status; the $300 \mathrm{~km}$ long Lyell Highway that connects the nearest settlement at Strahan to Hobart today was not completed until the mid-twentieth century, and tourism before this necessitated travel either by sea or private tour through wild country. Today, tourism to the island is not inexpensive, necessitating a long overland journey to Strahan and a concession of over AUD \$100 to gain passage on the only commercial ferries permitted to land on the island's jetty. The formal tourism trail through Macquarie Harbor strictly adheres to a route that includes Sarah Island, but excludes other sites in the former penal colony, such as nearby Grummet Island and the uninhabited harbor shores. Despite these limitations, commercial tourists do visit by the 
boatload (Fig. 4). Private tourism is also evidenced at some of these sites by worn walking trails and clearings maintained by an unofficial combination of Parks Service Rangers and local enthusiasts. Nevertheless, it is exclusive and expensive, requiring ownership or rental of a boat, and is thus primarily enjoyed by locals.

Convict settlement is not the only tourism draw to the area from which Sarah Island benefits. Sarah Island was added to the UNESCO World Heritage register as a cultural site in 1982, as part of the wider Tasmanian Wilderness area - a broad region comprised of the Franklin and Gordon Rivers, in addition to Macquarie Harbor into which these rivers drain. Beyond its notoriety as an outstanding natural wilderness and site of dark convict heritage, this remote region generates broader public awareness and political interest as a nationally significant focus of popular protest and civic action. The Franklin and Gordon Rivers were subject to a popular campaign from the late 1970 s to the early 1980s, when an attempt was made to construct a hydroelectric dam on the Franklin River. Popular support for "No Dams" on the Franklin below Gordon River became a divisive issue across Australia. The anti-dam campaign was a success, and retains a significant place in the popular history of both Tasmania and the "Mainland." As such, the UNESCO conservation area created after the campaign has itself become a national destination for ecotourism and green activism (Fig. 5).

The incorporation of Sarah Island into the World Heritage Area was a result of its geographic location, rather than perceived historic significance in the 1980s. Even today, the rainforest conservation area remains the primary aim of visiting boats ferrying tourists, with the stopover on Sarah Island simply a convenient addition to the half-day long trip. As a result of its incorporation onto the World Heritage register, however, Sarah Island became the first Australian convict heritage site to be given UNESCO World Heritage status, and is now maintained by the Parks and Wildlife Service of Tasmania. To support increased public interest in the area after the "No Dams" campaign, Parks installed the now-dismantled walkway over the old gaol

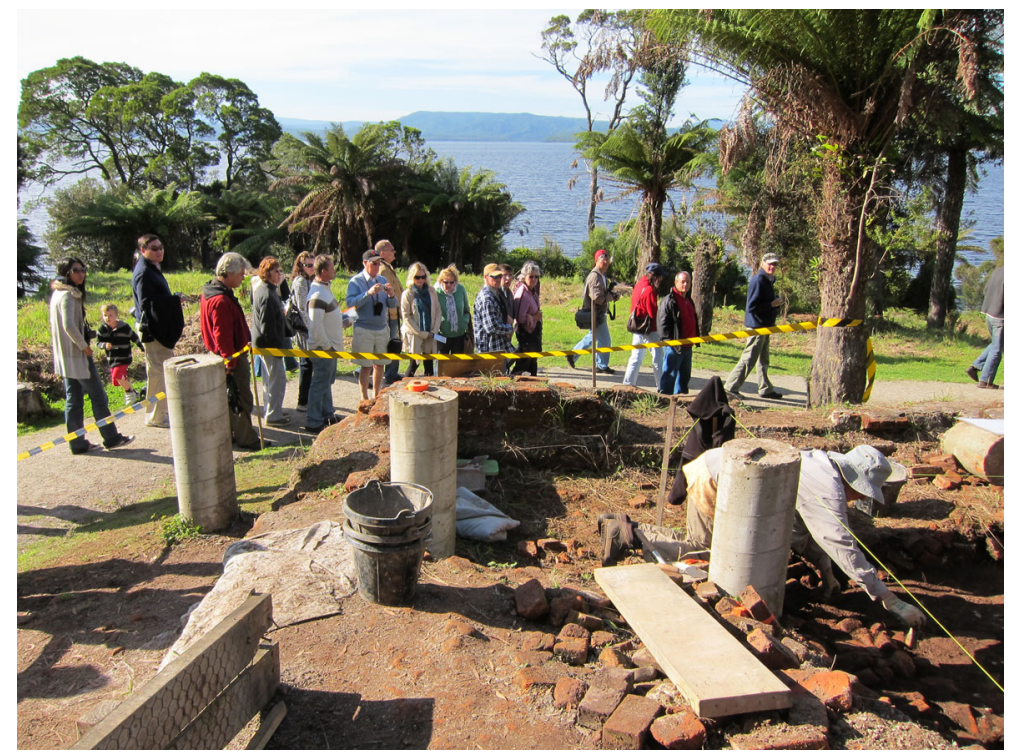

Fig. 4 Dark Tourism (Sarah Island Archaeology Project 2010) 


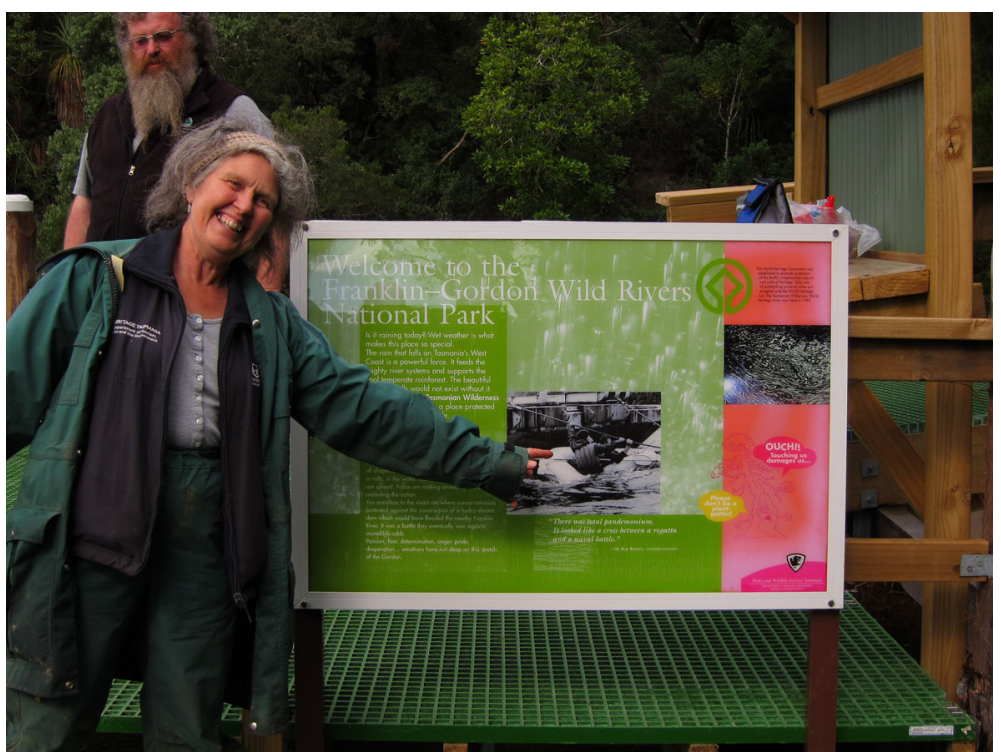

Fig. 5 An archaeologist and environmental activist, Angie McGowan was involved with the Franklin River Blockade during the 1980s. As Senior Archaeologist with the state heritage authority, she was part of the SIAP 2010 excavation team. During a survey visit of convict outstations located up the Gordon River, we discovered the new tourist information boards recently installed by the Tasmanian Parks and Wildlife Service. This image depicts Angie McGowan posing in front of an archival photo of herself on the Franklin River in a rubber dinghy during the Blockade Protests. Photo by Eleanor Conlin Casella

(McGowan 1986), and facilitated tours by establishing gravel pathways around the convict era ruins. The (partial) removal of the walkway in the last decade occurred because of Parks Service's increased awareness of the international archaeological significance of Sarah Island, and an attempt to manage tourist footfall over areas of particular concern. Unprecedented international interest in excavations at higher profile Tasmanian convict sites (particularly Port Arthur) also contributed to increased conscientiousness towards the commercial tourism infrastructure and visitor experience on this remote yet increasingly popular World Heritage Site. Thus, the site was once again incorporated into a government-associated institution, albeit one vastly removed from the purpose for which the colony was established.

Currently, commercial tourism operates under license by two private cruise companies who arrange half-day trips across Macquarie Harbor. These local businesses facilitate tourism at Sarah Island in partnership with a local thespian and history group - the Round Earth Company. Since 1993, this private company has staged a play about Sarah Island in the nearby village of Strahan. The company also offers guided tours of Sarah Island, which focus on the convict experience and treatment of inmates in the penal colony, and relates explicitly to their evening stage play. This commercialized tourist trade indicates a break from the official tourism industry of Tasmania, and represents the first organized and localized activity to take place on Sarah Island in the later-historic period outside of the context of a government institution.

For local residents, the Sarah Island site has seen frequent, non-official use since its closure. Shell casings from a shotgun and a rifle found in the topsoil of the gaol (see Table 1) suggest sporting activities on the island, with fowl as the most obvious target. 
Shell casings for a handgun indicate more suspect leisure activities, however. Lack of evidence of bullet damage in the rear of the gaol, and the location of the casings together suggest that a handgun was fired to the east, into the water, towards the direction of the unoccupied south-east bank of Macquarie Harbour. The very presence of this handgun is suspect; since 1996, possession of these weapons has been prohibited across Australia (Casella 1997). Discovery of handgun ammunition in the surface topsoil indicated a post-1996 date of deposit (and by extension, use). As such, it may be surmised that Sarah Island has been used as a private shooting range over the last two decades, likely by local people considering the inaccessibility of the island to tourists outside of business hours when such an activity would have been cause for notice. Operation of clandestine activity at this historic penal station has thus passed from the convicts in unhappy residence to the contemporary visitors of this remote island.

\section{Conclusions}

The vast network of colonial institutional sites established for convict transportation in Tasmania has left a significant material legacy, which, according to historians and cultural commentators, was rejected and ignored by the Australian public until relatively recently. As a material reminder of the "convict stain," the sites represented an undesirable colonial past and "dark" institutional heritage. The Macquarie Harbor penal colony on Sarah Island, which has remained isolated and unsettled since its final abandonment in 1847, represents an ideal site on which to explore how changing forms of tourism helped shape the evolving heritage of colonial institutions.

Sarah Island has undergone several incarnations, its material landscape transformed by these layers of intervention. Official visits and missions to the island while still in operation as a penal colony produced some of the earliest descriptions, and indicated a level of official curiosity about conditions and management. Archaeological evidence for picnicking throughout the Victorian period and up to the mid-twentieth century suggested that the site retained a significant position within the history of Tasmania - an infamy never abandoned in the wider public imagination. With the incorporation of Sarah Island into the UNESCO Tasmanian Wilderness site in 1982, commercial tourism ventures were established, and the allure of its dark colonial heritage became subsumed into broader commercial promotion of the unique natural history of the rivers, harbor, and rainforest. Mainstream celebration of Australia's colonial convict past over the last 50 years has increasingly encouraged commercial tourism to Tasmania's convict sites. And yet, despite a popular narrative of public censure of these sites, the material and historical record demonstrates an enduring ambivalence amongst both local populations and eager visitors towards these ghostly ruins.

Acknowledgments Co-Directed by Jody Steele (then of the Tasmanian Parks and Wildlife Service) and Eleanor Conlin Casella (University of Manchester, UK), the Sarah Island Archaeology Project was funded through a combination of the British Academy (UK) and the Tasmanian Parks and Wildlife Service. We would like to specially thank both Captain Chris Arthur (then Tasmanian Parks and Wildlife Service) for his site management, accommodation logistics, and daily boat transport, and Irene Arthur for much appreciated deliveries of fresh drinking water and artisan local cheeses. Michele Berry provided professional services as 
our site conservation specialist. Angie McGowan (then of Heritage Tasmania), Kirsten Brett and Lindy Bauer (both from the Tasmanian Museum and Art Gallery), Katherine Fennelly, Richard Tuffin, and Heather Bice all generously provided their expertise and enthusiasm as members of the project field crew.

Open Access This article is distributed under the terms of the Creative Commons Attribution 4.0 International License (http://creativecommons.org/licenses/by/4.0/), which permits unrestricted use, distribution, and reproduction in any medium, provided you give appropriate credit to the original author(s) and the source, provide a link to the Creative Commons license, and indicate if changes were made.

\section{References}

Alexander, A. (2013). The Ambitions of Jane Franklin, Allen and Unwin, Crow's Nest.

Backhouse, J. (1843). A Narrative of a Visit to the Australian Colonies, Hamilton, Adams, London.

Boow, J. (1991). Early Australian Commercial Glass, Heritage Council of New South Wales and New South Wales Department of Planning, Sydney.

Brand, I. (1984). Sarah Island, Regal Publications, Launceston.

Brand, I. (1990). The Convict Probation System: Van Diemen's Land 1839-1854, Blubber Head Press, Hobart.

Burn, D. (1842). Overland expedition of Sir John and Lady Franklin and suite to Macquarie Harbour and the Western Division of the Island, 1842, B 190/1, Mitchell Library, State Library of New South Wales, Sydney.

Casella, E. C. (1997). "To enshrine their spirits in the world": heritage and grief at Port Arthur, Tasmania. Conservation and Management of Archaeological Sites 2: 65-80.

Casella, E. C. (2001). Every procurable object: a functional analysis of the Ross factory archaeology collection. Australasian Historical Archaeology 19: 25-38.

Davies, M., and Buckley, K. (1987). Port Arthur Conservation and Development Project: Archaeological Procedures Manual, Tasmanian Parks and Wildlife Service, Hobart.

Hughes, R. (2010). The Fatal Shore, Random House, London.

Jones, O., and Sullivan, C. (1989). The Parks Canada Glass Glossary, Canadian Parks Service, Ottawa.

Lawrence, S., and Davies, P. (2011). An Archaeology of Australia Since 1788, Springer, New York.

Lennon, J., and Foley, M. (2000). Dark Tourism: the Attraction of Death and Disaster, Continuum, London. Maxwell-Stewart, H. (2008). Closing Hell's Gates, Allen and Unwin, Sydney.

McAtackney, L. (2014). An Archaeology of the Troubles: the Dark Heritage of Long Kesh/Maze, Oxford University Press, Oxford.

McGowan, A. (1986). Sarah Island Historic Site Archaeological Mitigation of Visitor Walkway Construction, 3rd-5th July 1985: Gaol, Bakehouse, Bank below Storekeepers Cottage, Unpublished report for National Parks and Wildlife Service of Tasmania, Hobart.

Miron, J. (2011). Prisons, Asylums, and the Public, University of Toronto Press, Toronto.

Oats, W. N. (1981). Backhouse and Walker: a Quaker View of the Australian Colonies, Blubber Head Press, Hobart.

Pétursdóttir, P., and Olsen, B. (2014). An archaeology of ruins. In Pétursdóttir, P., and Olsen, B. (eds.), Ruin Memories, Routledge, London, pp. 3-31.

Smith, L. J. (2006). Uses of Heritage, Routledge, London.

Stoler, A. L. (2008). Imperial debris: reflections on ruins and ruination. Cultural Anthropology 23: 191-219. Tasmanian Archives and Heritage Office. (1828). CSO 1/215/5188, 7 January 1828, Commandant to Colonial Secretary. Manuscripts of Ian Brand, 1984, "Macquarie Harbour Research," Gaol (2), Vol 1, p. 127. 